\title{
NILAI PENDIDIKAN DALAM UPACARA NYAMBLEH DI PURA PEREREPAN BANJAR DENJALAN DESA BATUBULAN KECAMATAN SUKAWATI KABUPATEN GIANYAR
}

\author{
Oleh: \\ I NYOMAN ALIT SUPANDI \\ Universitas Hindu Negeri I Gusti Bagus Sugriwa Denpasar \\ e-mail: alitsupandi85@gmail.com
}

Diterima: 29 September 2021, Direvisi: 06 Oktober 2021, Diterbitkan: 18 Oktober 2021

\begin{abstract}
Abstrak
Upacara nyambleh temasuk upacar bhuta yadnya direalisasikan ke dalam upacara Nyambleh, Umat Hindu di dalam praktek kehidupan sehari-hari selalu diwarnai upacara Yajna, sebagai wujud syukur kepada Ida Sang Hyang Widhi Wasa, atas segala berkah dan anugrah yang telah dilimpahkan pada umat manusia di bumi. Upacara nyambeleh ini wajib dilakukan dan memiliki keunikan yang dapat dijadikan salah satu tulisan. Secara umum tujuan penelitian ini bertujuan untuk mencari tahu bagaimana nilai pendidikan upacara Nyambleh di Pura Pererepan Desa Batubulan Kecamatan Sukawati Kabupaten Gianyar. Sehubungan dengan hal tersebut di atas, maka Upacara nyambleh ini sangat menarik untuk diteliti. Berdasarkan penjelasan di atas, dapat dirumuskan permasalahan yaitu: 1. Nilai pendidikan yang terkandung dalam upacara Nyambleh di Pura Pererepan Banjar Denjalan Desa Batubulan, Kecamatan Sukawati, Kabupaten Gianyar. Adapun hasil Nilai pendidikan yang terkandung dalam upacara Nyambleh di Pura Pererepan Desa Batubulan, ada empat yaitu 1. Nilai pendidikan tattwa yang dimaksud dalam upacara nyambleh adalah keyakinan masyarakat terhadap Ida Sang Hyang Widhi Wasa. 2. Nilai pendidikan religius ini terdapat pada masyarakat ngiring Petapaan atau Sesuunan sehabis itu masyarakat nunas pinget dan masyarakat tetap melaksanakan upacara nyambleh tersebut. 3. Nilai pendidikan etika yang terdapat pada upacara nyambleh adalah masyarakat melaksanakan ajaran tri kaya parisuda, bagaimana memiliki pikiran yang baik, perkataan yang baik, dan perbuatan yang baik dalam aktifitas masyarakat maupun dalam pelaksanaan upacara nyambleh. 4. Sedangkan nilai estetis yang terdapat dalam upacara nyambleh padasaat prosesi berlangsung bagaimana umbul-umbul yang berwarna warni, barong yang sangat indah disamping itu ada seni suara kidung maupun seni kerawitan maupun gambelan beleganjur.
\end{abstract}

Kata kunci: Nilai pendidikan, Upacara Nyambleh, Pura Pererepan

\begin{abstract}
The nyambleh ceremony, including the bhutayad ceremony, is realized in the Nyambleh ceremony. Hindus in their daily practice of life are always colored by the Yajna ceremony, as a form of gratitude to Ida Sang Hyang Widhi Wasa, for all the blessings and graces that have been bestowed on mankind on earth. This nyambeleh ceremony must be done and has a uniqueness that can be used as one of the writings. In general, this study aims to find out what the educational value of the Nyambleh ceremony is at Pererepan Temple, Batubulan Village, Sukawati District, Gianyar Regency. In connection with the above, the nyambleh ceremony is very interesting to
\end{abstract}


study. Based on the background of the problem above, the problems can be formulated, namely: 1. The educational value contained in the Nyambleh ceremony at the Pererepan Banjar Temple, Denjalan, Batubulan Village, Sukawati District, Gianyar Regency. The results of the educational value contained in the Nyambleh ceremony at the Pererepan Temple in Batubulan Village, there are four, namely 1. The value of tattwa education referred to in the nyambleh ceremony is the community's belief in Ida Sang Hyang Widhi Wasa. 2. The value of this religious education is found in the community accompanying the Hermitage or Sesuunan after that the Nunas Pinget community and the community continue to carry out the nyambleh ceremony. 3. The value of ethical education contained in the nyambleh ceremony is that the community carries out the teachings of tri Kaya parisuda, how to have good thoughts, good words, and good deeds in community activities and in the implementation of the nyambleh ceremony. 4 . While the aesthetic value contained in the nyambleh ceremony when the procession took place was how the colorful banners, very beautiful barong, besides that there was the art of kidung sound and the art of kerawitan and gambelan beleganjur.

Keywords: Educational value, Nyambleh ceremony, Pererepan temple

\section{PENDAHULUAN}

Pendidikan adalah usaha sadar untuk mengembangkan suatu kepribadian dan kemampuan manusia. Pendidikan adalah usaha sadar dan terencana untuk mewujudkan suasana proses pembelajaran agar peserta didik secara aktif mengembangkan potensi dirinya agar memiliki kekuatan spiritual keagamaan, mengendalikan diri, kecerdasan serta ketrampilan yang diperlukan dirinya, masyarakat, bangsa dan Negara. Pada zaman Upanisad merupakan sistem pendidikan dimana siswa duduk dekat dengan guru untuk mendengarkan suatu ajaran kerohanian. Jadi Upanisad artinya duduk dekat dibawah guru untuk mendengarkan ajaran-ajaran kesucian mengenai Tuhan. Kalau kita perhatikan pendidikan sekarang jauh beda dengan pendidikan yang terdahulu, tetapi tujuan pendidikan itu sama yaitu untuk memahami suatu ajaran, mencerdaskan pesrta didik, memupuk kedisiplinan dan lain sebagainya. Dalam kehidupan sehari-hari ini perlu kita lakukan untuk menjaga keharmonisan, di samping itu dalam pelaksanaan upacara pun pendidikan kedisiplinan harus dilakukan.

Upacara memiliki arti "mendekati”. Secara inti upacara agama merupakan aktifitas manusia untuk senantiasa mendekatkan diri kepada sesama dalam bentuk saling menghargai sesuai swadarmaning masing-masing, dekat kepada alam lingkungan dalam wujud menjaga kelestarian alam dan yang paling utama rasa lebih dekat dengan Tuhan Yang Maha Esa (Tim, 2000:112). Menurut Wiana (2007:42) Upacara adalah sebuah kata yang berasal dari bahasa Sanskerta yang berarti "mendekati". Di samping itu juga berarti "penghormatan". Inti upacara agama dalam tattwanya memang suatu aktifitas yang mendekatkan manusia dan alam lingkungannya dengan sesamanya dan dengan Tuhannya. Sebelum dapat mendekatkan diri kepada-Nya, hendaknya terlebih dahulu dapat menciptakan keseimbangan dan keselarasan serta keharmonisan dalam diri, agar dapat mewujudkan keharmonisan dengan Tuhan Yang Maha Esa

(Wijayananda, 2004:49).

Agama Hindu memahami ajaran tentang tri kerangka dasar yaitu tattwa yang menitik beratkan masalah filsafat atau inti ajaran agama Hindu, susila menekankan kepada pola prilaku yang berdasarkan etika, sedangkan upacara lebih difokuskan kepada acara ritual keagamaan. 
Ajaran tattwa dalam agama Hindu di Bali diimplementasikan ke dalam konsep keyakinan melalui ajaran Panca Sradha.(Suardana, 2010:7) manusia adalah mahluk yang serba ingin tahu. la ingin mengetahui setiap sebab dari suatu akibat. Ia ingin mengetahui mencari kebenaran hakiki, mengetahui sebab-sebab yang menyakinkan. Panca sradha dibagi menjadi lima yaitu : (1) Widhi Sradha yaitu keyakinan umat Hindu akan adanya Tuhan atau Ida Sang Hyang Widhi Wasa, (2)Atman Sradha artinya keyakinan umat Hindu akan adanya roh atau atman sebagai unsur pemberi jiwa pada semua mahluk, (3) Karma Phala Sradha yaitu kepercayaan bahwa setiap perbuatan membawa hasil sehingga terjadinya hubungan sebab akibat, (4) Purnarbawa Sradha artinya umat Hindu berkeyakinan bahwa kehidupan di dunia ini mengalami reinkarnasi atau kehidupan yang berulang-ulang, (5) Moksa Sradha yaitu keyakinan umat Hindu akan adanya kelepasan yang merupakan tujuan tertinggi dalam ajaran agama Hindu.

Ajaran Susila adalah ajaran yang menitik beratkan kepada tata aturan dalam bertingkah laku yang tertuang dalam konsep Tri Kaya Parisudha adapun bagian Tri Kaya Parisudha adalah (1) Manacika Parisuda yaitu berpikir yang suci, (2) Wacika Parisudha yaitu berkata yang benar, (3) Kayika Parisudha yaitu berbuat yang benar.

Ajaran Upacara diimplementasikan dalam konsep panca yadnya. Adapun bentukbentuk yadnya yaitu ada yadnya dalam bentuk ibadah yang dilakukan dengan ritual dan yadnya dalam bentuk tindakan yang diwujudkan dalam bentuk tingkah laku. Yadnya dalam bentuk ibadah dalam keyakinan agama Hindu dilakukan dengan melakukan Panca Yadnya yaitu lima jenis ritual dalam keyakinan umat Hindu yang terdiri dari Dewa Yadnya, Pitra Yadva. Rsi Yadnya, Manusa Yadnya dan Bhuta Yadnya.

Dewa Yadnya berarti (persembahan suci ditunjukkan kehadapan Tuhan Yang Maha Esa dan para dewa serta segala manifestasinya). Pitra Yadnya berarti (persembahan suci kehadapan pitra atau roh leluhur dan termasuk kepada orang tua yang masih hidup). Dari pada itu putra-putri harus tetap menghormati orang tua, karena kita berhutang budi kepadanya. Pitra yadnya, yang disesuaikan dengan tingkat dan kedudukan seseorang "Desa-Kala-Patra dan Nista-Madya-Utama" (Purwita 1992 : 19 - 35). Rsi Yadnya berarti persembahan suci kepada Brahmana atau para Rsiatas jasa beliau dalam membina umat dan mengembangkan ajaran agama.Manusa Yadnya adalah (persembahan suci kehadapan sesama).Tujuan melaksanakan korban suci ini untuk pembersihan lahir dan batin.Pembersihan lahir batin ini dilakukan setiap hari, setiap saat, dan berkelanjutan sehingga atman dapat menunggal dengan parama atman.Bhuta Yadnya adalah (persembahan suci yang ditunjukkan pada bhuta kala). Tujuannya persembahan suci itu adalah untuk memelihara, menyucikan dan nyupat kehidupan manusia.Disamping itu adapun tujuan upacara bhuta Yadnya adalah untuk memohon kehadapan Sang Hyang Widhi Wasa (Tuhan Yang Maha Esa) agar Beliau memberi kekuatan lahir batin, juga untuk menyucikan dan menetralisir kekuatan-kekuatan yang bersifat negatif yang disebut bhuta kala tersebut sehingga dapat berfungsi dan berguna bagi kehidupan manusia.

Berdasarkan tulisan ini memfokuskan kepada upacara bhuta yadnya direalisasikan ke dalam upacara Nyambleh, masyarakat desa adat jro kuta di dalam praktek kehidupan sehari-hari selalu diwarnai upacara Yajna, sebagai wujud syukur kepada Ida Sang Hyang Widhi Wasa, atas segala berkah dan anugrah yang telah dilimpahkan pada umat manusia di bumi. (Sudharta, 2001:5) Menjelaskan pelaksanaan kegiatan upacara agama Hindu bersumber pada ajaran Weda.Suatu upacara dalam agama Hindu selalu disertai dengan upakara, baik dalam wujud kecil (sederhana), menengah (madya), maupun yang utama. Pelaksanaan upacara hendaknya dibarengi dengan memahami akan makna dan tujuan dari upacara yang dilaksanakannya, karena suatu upacara dan upakara adalah sebagai wujud dari pengejawantahan dari tattwa (filsafat) yang bersumber dari ajaran 
agama Hindu, maka dari itu suatu upakara atau bebantenan hendaknya harus mengacu pada sastra-sastra agama (Ngurah, 2005:30-31).

Kejadian dimasyarakat khususnya di Desa Adat Jro Kuta Batubulan tidak ada yang berani tidak melaksanakan upacara Nyambleh, inipun harus dilaksanakan karena masyarakat memiliki kepercayaan bahwa pretima atau sesuunan memiliki kekuatan sehingga masyarakat memiliki sujud dan bhakti dengan melaksanakan upacara Nyambleh. Memang Kebudayaan Bali tidak bisa dipisahkan dengan agama Hindu. Ajaran agama Hindu memegang memiliki perananpenting dalam kehidupan seni dan budaya, di mana ajaran agama sebagai nafasnya seni budaya yang berurat sangat dalam, sehingga melahirkan seni budaya yang sosial relegius. Praktek-praktek agama memberi warna dan sekaligus mendorong perkembangan seni budaya. Kebudayaan Bali sesungguhnya menjunjung tinggi nilai-nilai keseimbangan dan harmonisasi mengenai hubungan manusia dengan Tuhan (parhyangan), hubungan sesama manusia (pawongan), dan hubungan manusia dengan lingkungan (palemahan), yang tercermin dalam ajaran Tri Hita Karana (tiga penyebab kesejahteraan). Apabila manusia mampu menjaga hubungan yang seimbang dan harmonis dengan ketiga aspek tersebut maka kesejahteraan akantenwujud dengan melaksanakan persembahan suci yang tulus iklas (Ngurah, Dkk.2006:99).

Kalau kita cermati fenomena di masyarakat memang benar masyarakat Jro Kuta Batubulan tetap melaksanakan upacara nyambleh dengan hati yang tulus ikhlas. Alasan menulis upacara nyambeleh ini, dalam pelaksanaan sangat unik. Keunikan pada saat upacara ini adalah pretime atau sesuunan mengelilingi wilayah, istilahnya disini mececingak, sesampai di Pura Dalem Taak dilaksanakan penyambleh dan menggunakan kucit bhutuan. Ini menjadi peneliti untuk tertarik melaksanakan suatu penelitian dengan judul Nilai pendidikan dalam upacara Nyambleh di Pura Pererepan Banjar Denjalan Desa Batubulan, Kecamatan Sukawati, Kabupaten Gianyar.

Dari uraian yang disampaikan di atas, adapun permasalahan yang diangkat pada penelitian ini adalah nilai pendidikan yang terkandung dalam upacara Nyambleh di Pura Pererepan Banjar Denjalan, Desa Batubulan, Kecamatan Sukawati, Kabupaten Gianyar.

Adapun tujuan dari dilaksanakannya penelitian ini adalah: secara umum penelitian ini bertujuan untuk mencari tahu bagaimana nilai pendidikan upacara Nyambleh di Pura Pererepan Desa Batubulan Kecamatan Sukawati Kabupaten Gianyar. Secara Khusus tujuan yang ingin dicapai dalam tulisan ini adalah untuk mengetahui nilai pendidikan yang terkandung dalam upacara Nyambleh di Pura Pererepan Desa Batubulan, Kecamatan Sukawati, Kabupaten Gianyar.

\section{METODE}

Dalam sebuah penelitian metode merupakan langkah yang sangat penting karena metode dapat menentukan salah benarnya proses suatu penelitian dan berhasil tidaknya sebuah penelitian (Raharjo, 2012:16). Peneliti hendaknya dapat memilih dan menentukan metode yang tepat dan mungkin dilaksanakan, guna mencapai tujuan penelitian, karena itu perlu mengetahui metode ilmiah dalam penelitian. Metode penelitian merupakan usaha untuk menemukan, mengembangkan dan menguji kebenaran suatu pengetahuan. Metode juga berarti suatu cara untuk menganalisa fakta dan teori yang tersusun baik untuk mencapai sesuatu (Suryabrata, 2003:10).

Metode adalah suatu cabang ilmu yang mempelajari cara-cara melakukan pengamatan yaitu meliputi kegiatan-kegiatan mencari, mencatat, merumuskan, menganalisa sampai menyusun laporan berdasarkan fakta-fakta atau gejala-gejala secara ilmiah (Narbuko, 2003:03). Berdasarkan uraian diatas dapat dipahami bahwa 
metode dalam penelitian ini merupakan cara untuk mengadakan penelitian sehingga kebenaran karya tulis ini dapat dipertanggung jawabkan secara ilmiah, atau diartikan sebagai cara kerja yang tersistem untuk memudahkan pelaksanaan suatu kegiatan guna mencapai tujuan yang ditentukan. Dengan demikian metode penelitian adalah alat untuk mengambil kesimpulan, menjelaskan dan menganalisa masalah sekaligus merupakan alat untuk memecahkan masalah tersebut atau dengan kata lain perwujudan dari metode berpikir. sebelum melakukan penelitian dengan menggunakan metode yang direncanakan, maka terlebih dahulu diperlukan adanya penjajakan dan penelitian lapangan. Dengan melakukan penjajakan ke lokasi, penelitian dapat memiliki gambaran umum tentang geografi, demografi, sejarah, adat istiadat, agama, pendidikan, kebiasaan-kebiasaan, mata pencaharian serta tokoh-tokoh masyarakat setempat (Moleong, 2003:88). Dari sekian pendapat diatas dalam melakukan tulisan ini, jenis tulisan yang digunakan adalah kualitatif. Teknik Pengumpulan Data melalui observasi, wawancara objek yang dicari adalah pemangku, masyarakat atau tokoh masyarakat yg mengetahuwi dan memahami terkait tulisan ini, studi dokumentasi, studi kepustakaan. Inilah metode yang di gunakan dalam tulisan ini.

\section{HASIL DAN PEMBAHASAN}

\subsection{Nilai Pendidikan dalam upacara Nyambleh di Pura Pererepan Banjar Denjalan Desa Batubulan, Kecamatan Sukawati, Kabupaten Gianyar}

\subsubsection{Nilai Pendidikan Tattwa}

Sebelum membahas nilai Pendidikan tattwa dalam Upacara Nyambeleh terlebih dahulu akan diuraikan pengertian tattwa. Tattwa berasal dari bahasa sanskerta yaitu dari urat kata "Tat" yang berarti itu, yang tiada lain adalah Tuhan. Sedangkan "Twa" yang berarti bersifat. Maka Tattwa berarti suatu hakekat atau suatu kebenaran (Sura, Dkk, 1985: 14). Tattwa adalah hakikat atau kebenaran suatu unsur baik yang nyata maupun yang tidak nyata hakikat dari Hyang Widhi (Subagiasta, 2006: 7). Tattwa berarti hakikat, atau kenyataan yang sesungguhnya. Suatu pengetahuan mengenai hakikat atau kenyataan yang sesungguhnya tentang Hyang Widhi (Nurkancana, 2002: 5). Sehingga dapat dikatakan bahwa tattwa adalah hakekat kebenaran itu sendiri yaitu Tuhan, oleh karena itu cara pandang mengenai kebenaran itu berbeda-beda tetapi sebenarnya itu satu adanya, pendidikan tattwa adalah suatu pendidikan yang mempelajari tentang aspek keTuhanan, maka dari itulah manusia berfilsafat. Tattwa atau filsafat merupakan konsepsi yang menyeluruh tentang Tuhan, alam semesta dan manusia, Nilai serta norma-norma yang dapat dipakai sebagai dasar dalam sikap serta perbuatan manusia dalam hubungannya dengan dirinya sendiri, alam semesta dan pencipta-Nya (Tuhan). Kemudian dalam hubungannya pendidikan tattwa yang terdapat pada upacara Nyambeleh adalah sebagai berikut.

Giri mengatakan bahwa : Nyambleh adalah upacara yang dinyakinni oleh masyarakat untuk keharmonisan suatu hubungan baik manusia dengan tuhan, baik itu manusia dengan manusia, maupun manusia dengan lingkungan. sudah tentu memiliki makna tattwa yang sangat mendalam. Hal ini dapat dilihat dari kesakralan upacara nyambleh, karena kita menyadari bahwa semuanya adalah tuhan, tuhan adalah semua, semua ini adalah tuhan. Inilah hakikat didalam Upacara Nyambleh dan untuk mendekatkan diri, selalu ingat dengan tuhan. Karena tuhan adalah asal dari semua yang ada di dunia ini baik itu Bhuana Agung maupun Bhuana Alit.Inilah Salah satu ajaran tattwa yang dilakukan di pura perepan dengan melaksanakan upacara Nyambleh untuk menjaga keharmonisan. Dapat kita lihat foto dibawah ini; 


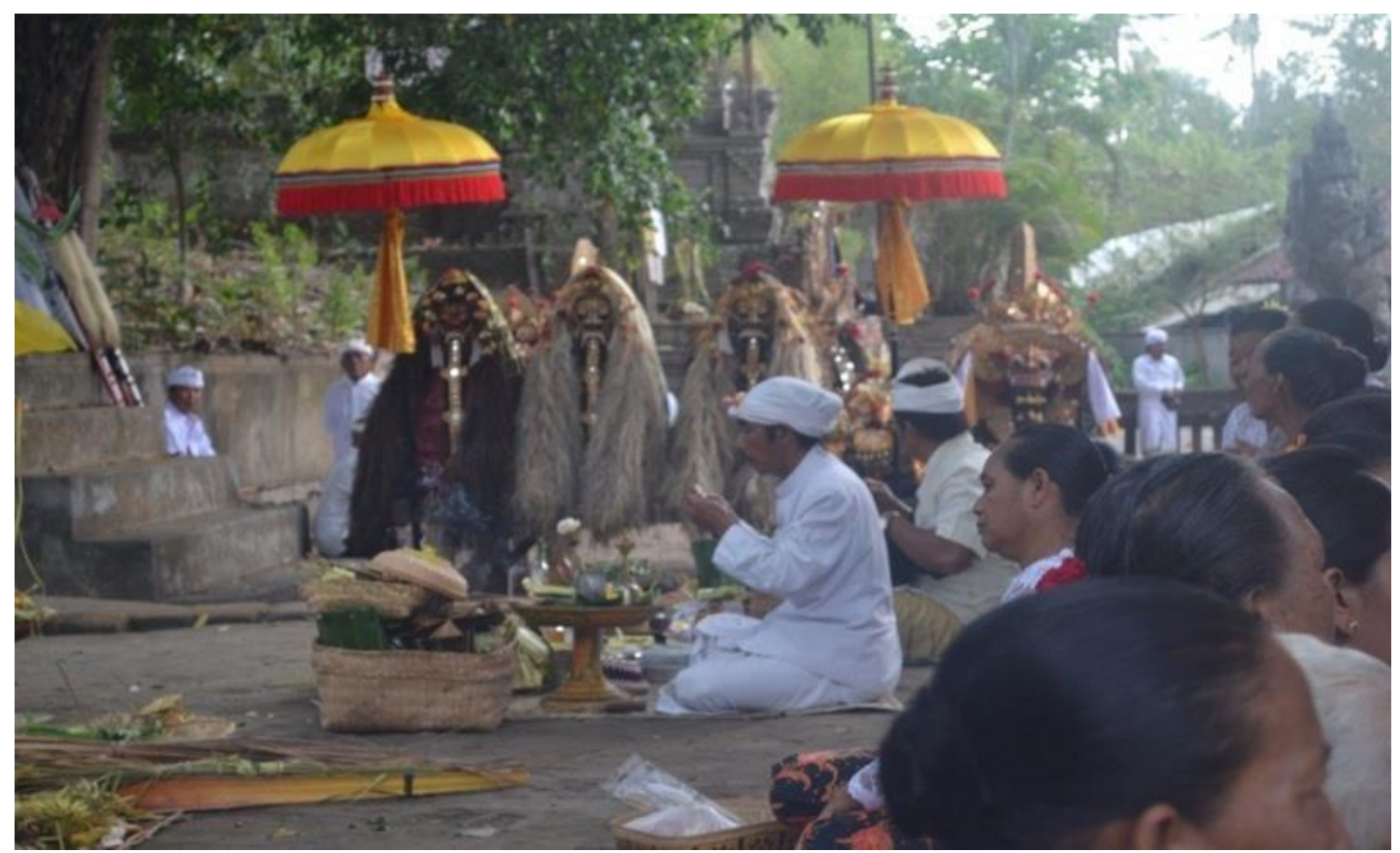

Foto 1 Jro mangku sedang ngaturan piuning di Pura Dalem

Kalau kita kaitan foto ini dengan innforman sangat jelas atau sangat berkaitan, bahwa nilai tattwa dalam upacara Nyambleh bisa dilihat pada saat jero mangku memohon keharmonisan, kedamaian di areal pura dalem Taak tepatnya di pengulun setra bahwa dapat kita yakinni Dewa Siwa berstana dipura Dalem, menurut lontar

Bhuana Kosa Bhatara Siwa sumber segala, dikatakan bahwa semua yang ada ini muncul dari Bhatara Siwa dan akan kembali kepada-Nya juga. Dengan demikian maka Bhatara Siwa adalah sumber segala yang ada. Sakwehning jagat kabeh, mijil sangkeng Bhatāra Śiwa ika, lina ring Bhatāra Śiwa ya. Semua dunia ini muncul dari Bhatara Siwa, lenyap kembali pada Bhatara Siwa juga. (Bhuwanakosa III.82).

Segala yang muncul dari Bhatara Siwa itu sifatnya maya, bukan yang sesungguhnya dan merupakan dunia fenomena yaitu dunia gejala yang tampak untuk sementara saja. Ibarat tampaknya bayang-bayang pada cermin, yang tampaknya saja ada namun sesungguhnya tidak ada, dan yang sesungguhnya ada berada di balik bayang-bayang itu. Adapun yang sembunyi di balik dunia ini, yang bersifat langgeng, hanyalah Bhatara Siwa sendiri. Bhuwanakosa menyatakan sebagai berikut :Ikang jagat kabeh, sthāvara janggamā-waknya, māya swabhawanya, rupa Bhatāra Śiwa sahananya, ikang rāt kabeh, $i$ wěkasan lìna mare sira. Semua dunia ini, tumbuh-tumbuhan, binatang wujudnya, maya sifatnya, wujud Bhatara Siwa itu semuanya, semua dunia ini pada akhirnya lenyap kepadaNya (Bhuwanakosa III.81).

\section{Tatvāni sanharet bhuyah \\ liyante tatvake punah, salīlān eka tat sarvve, dåûtopi vuvudhah yathā.}

Terjemahannya : 
Mangkana pwa Bhatāra Śiwa, irikang tattwa kabeh, ri wekasan līna ri sira muwah, nihan drstopamanya, kadyangganing wěrěh makweh wijilnya tunggal ya sakeng wway.

Demikianlah Bhatara Siwa, pada semua tattwa, pada akhirnya kembali lagi ke dalam dirinya, contohnya seperti halnya buih banyak munculnya (namun sesungguhnya) tunggal dari air (Bhuwanakosa III.71).

Dalam hubungan inilah Bhatara Siwa dipandang sebagai Pencipta, Pemelihara dan Pamrelina segala yang ada.

Brahmā srjayate lokam, viûóave pālakā sthitam, rudretve sangharaś ceva, trimūrtih nāma eva ca.

Terjemahannya :

Lwir Bhatāra Śiwa magawe jagat, Brāhma rūpa sirān panåûti jagat, Wiûóu rūpa sirān pangrakûa ng jagat, Rudra rūpanira mralayakěn rāt, nāhan tāwak nirān tiga, bheda nama. (Bhuwanakosa III.78)

Halnya Bhatara Siwa menciptakan dunia ini, Brahma wujudNya waktu menciptakan dunia ini, Wisnu wujudNya waktu menjaga dunia ini, Rudra wujudNya waktu memrelina dunia ini. Demikianlah tiga wujudNya (Trimurti) hanya beda nama.

Berdasarkan keterangan informan dan lontar Bhuana Kosa di atas dijelaskan bahwa pengungkapan nilai pendidikan tattwa dalam upacara Nyambleh adalah kepercayaan yang dinyakinni umat manusia yang mendalam terhadap keberadaan Tuhan beserta manifestasi-Nya (Widhi Sraddha), yang menjadi landasan konseptual bagi umat Hindu untuk melaksanakan upacara Yadnya, kalau kita mengacu kepata lontar bhuana Kosa memang semuanya ini diciptakan oleh siwa akan tetapi jika kita mengacu ke dalam konsep Tri murti, Dewa Brahman adalah sebagai pencipta, Dewa Wisnu adalah sesebagai pemelihara sedangkan Dewa Siwa adalah sebagai prelinaini yang kita yakinni didalam konsep Tri murti. Khususnya dalam kepercayaan masyarakat, semuanya ini benar dan tidak bisa di pisahkan, semuanya harus kita puja, sembah dan tidak boleh kita membedakan satau dengan yang lainnya, semuannya ini adalah sama memiliki tugas dan fungsinya masing-masing, seperti foto di bawah ini. 


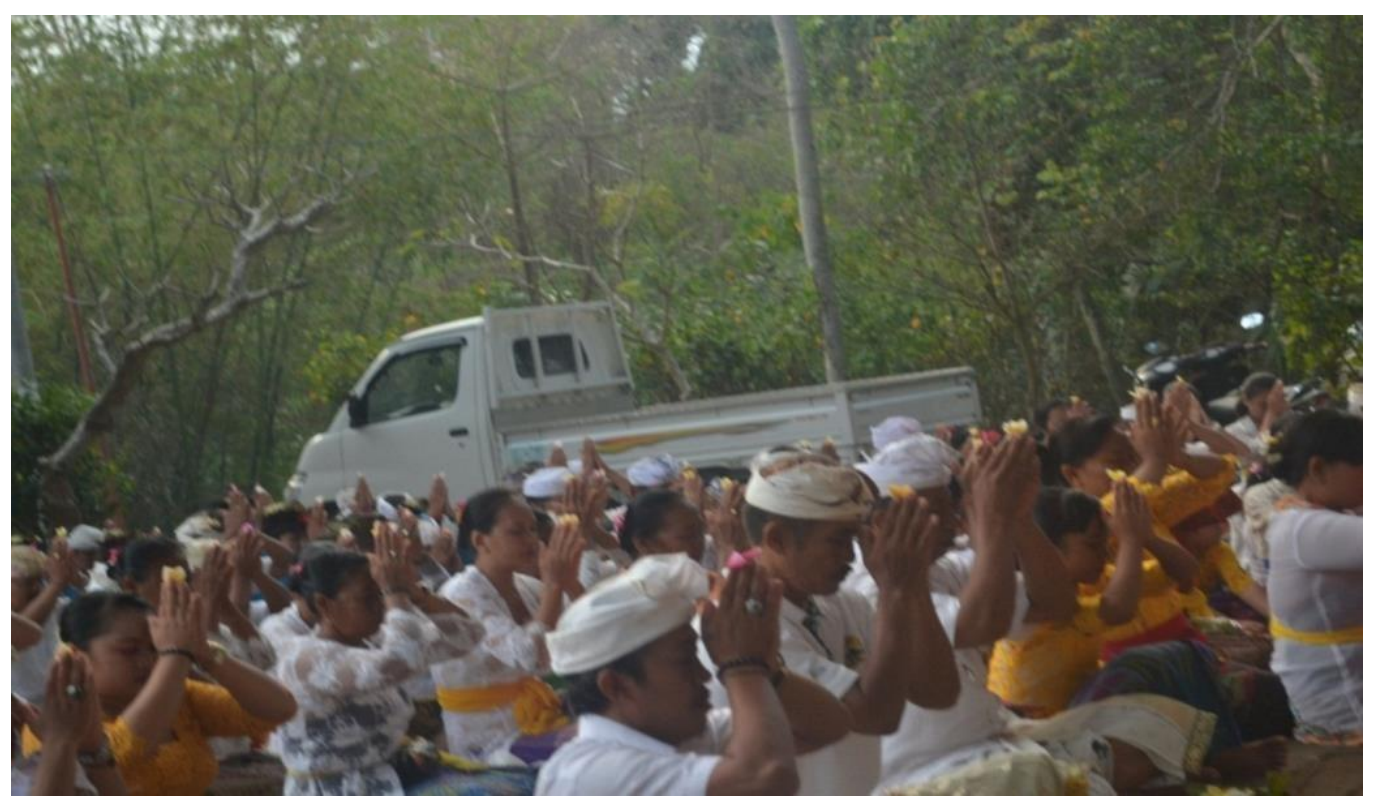

Foto 2 Masyarakat sedang melaksanakan pemujaan atau sembah bhakti

Foto diatas dapat kita lihat bahwa inilah perwujudan rasa sembah bhakti umat manusia kepada Ida Sang Hyang Widhi Wasa, salah satu dengan mengaturkan sarana dan praserana persembahan kepada Ida Sang Hyang Widhi Wasa. ini merupakan suatu wujud keyakinan warga masyarakat kepada Ida Sang Hyang Widhi Wasa, supaya mendapatkan keselamatan dan kerahayuan atau keharmonisan dan ketentraman kita bersama. Kehidupan masyarakat sangat kental dengan nuansa Tattwa, dan benar-benar mengikuti hal-hal yang diwariskan dari generasi sebelumnya. Hal ini nampak jelas tata kehidupan masyarakat sangat beragama, sehingga masyarakat lebih mendekatkan diri kehadapan Ida Sang Hyang Widhi Wasa atau Tuhan Yang Maha Esa, inilah nilai tattwa yang terdapat dalam pelaksanaan upacara Nyambleh.

\subsubsection{Nilai Pendidikan Religius}

Religius berkaitan dengan kepercayaan atau keyakinan masyarakat. Taman mengatakan bahwa selesai melakukan upacara Nyambleh masyarakat menggunakan Benang Tri Datu masyarakat menyebutnya benang pinget. Ini pun dinyakinni oleh masyarakat bahwa jika menggunakan benang ini, akan selalu dilindungui dan dihindari oleh hal yang tidak kita inginkan. Misalnya seperti wabah penyakit dan lain sebagainya. Religius pelaksanaan upacara Nyambleh juga terdapat dalam pelaksanaannya seperti, petapakan atau bisa disebut Ide Sesuunan mengelilingi wilayah lingkungan masyarakatpun ikut ngiring ke bucu-bucu wilayah banjar Denjalan Batur, tujuannya untuk menetralisir kekuatan yang negatif menjadi kekuatan yang positif. masyarakat juga memiliki kepercayaan bahwa pada saat upacara nyambleh Ide Sesuunan di percayai mececingak atau melihat-lihat sehingga kalau ada sesuatu yang tidak diinginkan bisa di netralisir pada saat itu juga. Pada saat mececingak atau mengelilingi wilayah ada di beberapa tempat melaksanakan upacara pecaruan seperti di prempatan ini bisa dilihat pada foto dibawah ini: 


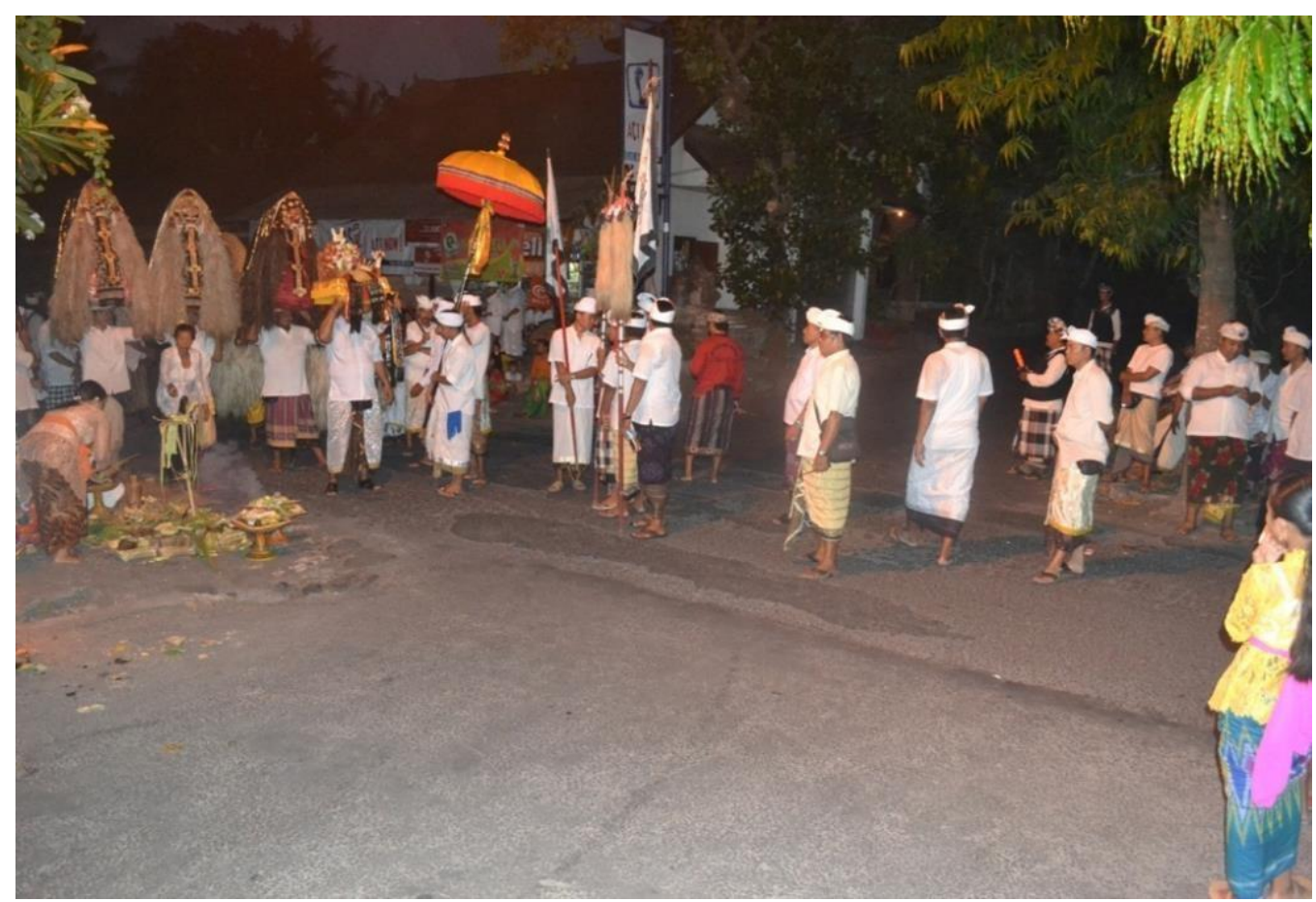

Foto 3 Melaksanakan pecaruan di prempatan

Foto diatas sangat jelas petapakan atau Ide Sesuunan, pemangku dan masyarakat sedang melaksanakan pecaruan di perempatan jam setengah tuju malam, ini sangat jelas religius masyarakat di implementasikan dalam bentuk upacara Nyambleh. Ini mencerminkan sradha masyarakat sangat kuat atau baik. Didalam agama hindu mengenal istilah ajaran panca sradha yaitu:

1. percaya dengan adanya Tuhan Yang Maha Esa (Widhi Tattwa);

2. percaya adanya Atma atau roh (Atma Tattwa);

3. percaya adanya hukum karma phala(karma phala tattwa);

4. percaya adanya samsara(punarbawa tattwa); dan 5. percaya adanya moksa (moksa tattwa) (PHDI, 2000: 14).

Lima kepercayaan umat Hindu ini merupakan Sradha terhadap keberadaan Tuhan Ida Sang Hyang Widhi Wasa. Seperti yang telah diungkapkan di atas, dapat diketahui bahwa konsep sradha itu telah menjiwai upacara Nyambleh. Konsep religius dan sradha yang ditekankan pada hasil pendapat di atas, merupakan Manusia adalah mahluk yang paling sempurna dari ciptaan Tuhan karena manusia memiliki kelebihan untuk berpikir, berkata dan berbuat. Dengan pikiran manusia bisa merubah nasibnya dan memperbaiki dirinya seperti apa yang telah di paparkan dalam Sarasamuccaya adalah sebagai berikut:

Mānuşah sarvabhütesu vartate vai cubhacubhe, acu bhesu sama vistam cubhesvevāvakārayet

Terjemahannya:

Dari demikian banyaknya mahluk yang lahir sebagai manusia itu saja yang dapat berbuat baik dan buruk, kemampuan melebur perbuatan buruk ke dalam perbuatan baik demikianlah pahalanya menjadi manusia. 
Kutipan Sarasamuccaya di atas menunjukkan bahwa manusia memiliki kesempatan untuk merubah dirinya dengan penguasaan pikiran. Religius atau agama tidak bisa terlepas dengan tradisi kebudayaan yang ada di masyarakat Khususnya di Bali, karena religius merupakan bagian dari unsur kebudayaan itu sendiri. Unsur kebudayaan yang disebut dengan religi sangat kompleks dan berkembang. Bila ditinjau secara mendalam unsur budaya yang disebut religi pada hakekatnya kompleks, namun demikian Nampak adanya lima unsur religi yang saling berkaitan antara yang satu dengan yang lainnya: 1) Emosi keagamaan,2) Sistem kepercayaan, 3) Umat penganut agama, 4) Peralatan upacara, 5) Sistem upacara. Kelima unsur tersebut merupakan satu kesatuan yang bulat yang tidak dapat dipisahkan.

Berdasarkan pendapat diatas dapat di petik bahwa didalam upacara nyambleh, religius masyarakat memang ada di implementasikan dalam bentuk upacara nyambleh. Salah satunya benang tri datu, dapat menetralisir yang negative ke positif, ngiring ida Sesunan. Mengaturkan kucit bhutuan, memberikan pecaruan di beberapa perempatan, Sistem kepercayaan, umat penganut agama, peralatan upacara dan lain sebagainya, inilah religius yang terdapat dalam prosesi upacara nyambleh.

\subsubsection{Nilai Pendidikan Etika}

Etika dalam agama Hindu tidak bisa dilepaskan dari kitab suci Weda yang merupakan dasar dari segala aturan tata susila. Kata etika berasal dari bahasa Yunani yaitu ethos yang berarti watak kesusilaan atau adat kebiasaan. Etika berkaitan erat dengan moral, etika adalah ilmu tentang apa yang baik dan apa yang buruk tentang hak dan moral. Etika adalah pengetahuan tentang kesusialaan, yang berbentuk kaidahkaidah yang berisi larangan-larangan untuk berbuat sesuatu. Dalam etika akan didapati ajaran tentang perbuatan baik dan perbuatan buruk. Menurut Alex (2005:163) dalam kamus ilmiah popular kontemporer, etika adalah kaidah-kaidah yang membimbing manusia untuk mengatur kelakuannya sehingga menjadi lurus dan baik dalam keselarasan antara individu masyarakat, semesta alam dan Tuhan. Sedangkan kata etika dalam bahasa Indonesia lebih tepat dengan perkataan kesusialaan atau tata susila yang terdiri dari kata "su" yang mempunyai arti baik, sesuai, dan "sila" adalah dasar. Jadi susila adalah tingkah laku manusia harus sesuai dengan dasar-dasar atau norma-norma, dalam upacara Nyambleh ajaran etika yang terdapat adalah sebagai berikut:

Ariyani mengatakan Upacara Nyambleh merupakan suatu tindakan atau tingkah laku yang selalu patuh kepada aturan-aturan, kaedah dan keyakinan yang muncul dari pikiran dan didasarkan akal sehat yang menjadi kebiasaan, tidak menyimpang dari tata susila yang diikuti secara turun temurun. Dalam hal ini konsep Tri Kaya Parisudha (tiga dasar prilaku yang harus disucikan), Dengan perbuatan yang baik dan benar akan memperoleh hasil yang baik pula, jika kita berbuat tidak baik sebetulnya kita tidak berani, karena kita meyakinni dengan istilah karmaphala, apapun yang kita lakukan itulah asilnya, ibaratkan seperti menabung jika kita sering menabung pasti akan banyak memiliki uang, dan uang ini di kemudian hari akan kita yang menikmatinya, ini sama seperti dalam melaksanakan aktifitas sehari-hari didasari perbuatan yang baik, dan sebaliknya jika berbuat tidak baik maka hasilnya tidak baik pula. Manusia sebagai makhluk yang mempunyai akal dan pikiran selalu berusaha berbuat yang baik dan benar demi kebahagiaan dirinya sendiri dan semua makhluk hidup di dunia ini. Pelaksanaan upacara nyambleh sebagai pencerminan dari Tri kayika parisudha, ini terlihat dalam berbagai aspek kegiatan, dalam hal membuat upakara atau banten, faktor kesucian sangatlah ditentukan. Orang dalam keadaan cuntaka tidak boleh ikut mengerjakan banten, tidak boleh memasuki Pura atau tempat suci, apalagi mengikuti persembahyangan. Apapun itu proses pembuatan banten harus didasari etika yang baik. 
wacika (berkata yang baik), Wacika Parisudha artinya berkata atau berbicara yang baik dan benar. pada saat ngayah di Pura perepan masyarakat pengempon pura tidak boleh berkata kasar dengan temannya maupun pemangunya karena Perkataan merupakan cerminan kepribadian seseorang, disamping gerak-geriknya, dari mendengarkan perkataan, orang akan dapat mendatangkan kebahagiaan untuk diri sendiri atau menarik simpati orang lain, tetapi jika sebaliknya akan menjadi racun yang menghancurkan atau membawa malapetaka bagi seseorang. Pada saat ngayah memiliki kesadaran dan yakin bahwa dengan tidak berbicara yang kasar akan mendapatkan perlindungan dari Ida Bhatara Sesuwunan. Perkataan memang hendaknya selalu dijaga, atau dikontrol agar tidak terjadi hal-hal yang bersifat negatif. Menjaga perkataan sesungguhnya merupakan jalan untuk mendapatkan keharmonisan. Masyarakat selalu memiliki rasa bhakti kepada Ida Sang Hyang Widdhi Wasa. Oleh sebab itu, hal pertama yang harus diperhatikan adalah pikiran. Pikiran yang tulus iklas bhakti pastilah akan mendasari kesuksesan dan keberhasilan pelaksanaan dalam sebuah yadnya atau upacara nyambleh. Prosesi upacara Nyambleh tentu memiliki nilai etika terutama etika yang dilandaskan pada konsep manacika parisudha yang artinya pikiran yang baik., bahwa manusialah yang paling sempurna di antara tiga makhul lain sebagai ciptaan Tuhan. Sebagai pemilik pikiran, maka seharusnya manusia yang menguasai pikiran, bukan sebaliknya. Hal itulah yang ditekankan pada prosesi Nyambleh, bahwa dengan konsep ngayah yang dilaksanakan dengan tulus, pikiran diarahkan, dikendalikan untuk selalu berpikir yang baik didalam proses upacara Nyambleh.

Berdasarkan uraian diatas nilai pendidikan etika yang terdapat dalam upacara Nyambleh adalah mendidik dan membina masyarakat untuk hidup saling menghormati, melaksanakan ajaran tatwamasi dan mengamalkan ajaran Tri Kaya Parisudha bertingkah laku yang baik, berbicara yang baik, mempunyai pikiran yang benar, seperti di jelaskan dalam kakawin Nitisastra bab V sloka 3 disebutkan sebagai berikut:

\section{Wasita nimittanta manemu laksmi \\ Wasita nimittanta pati kapangguh \\ Wasita nimittanta manemu dukha \\ Wasita nimittanta manemu mitra}

Terjemahan :

Oleh perkataan engaku akan mendapatkan kebahagiaan,

Oleh perkataan engaku akan mendapatkan kematian,

Oleh perkataan engaku akan mendapatkan kesusahan, Oleh

perkataan engaku akan mendapatkan sahabat.

(Tim Penyusun, 1971:37).

Kakawin Ramayana memaparkan bahwa:

Ragadi musuh mapare, ri

hati ya tongwannya tan

madoh ringawak, yěka

tan hana ri sira,

prawira mihikan sirěng niti

Terjemahannya : 
Nafsu dan sebagainya adalah musuh yang sangat dekat, di dalam hatilah tempatnya tidak jauh dari diri, hal itu tidak ada pada dirinya, berani dan bijaksana beliau menjadi raja (Murta dan Mergeg,1971: 14).

Rasa kebersamaan ini secara tegas disebutkan di dalam Reg Veda X. 191.2-4; sebagai berikut :

Sam gacchadvam sam vadadhvam sam manam sijanatam, deva bhagam yatha purve samjanana upaseta ; Samano mantrah samitih samani samanam manah saha sitta esam, sahomi, samani va akutih samana hrdayani vah, samanam astu vo mano yatha vah susahasati.

Terjemahannya:

Adakanlah pertemuan, berembuglah agar engakau mencapai kesepakatan. Seperti para Dewa bersama-sama menikmati persembahan. Capailah tujuan bersama, kesepakatan bersama. Satu dalam pikiran menuju satu tujuan. Aku canangkan suatu tujuan bersama bagi engakau sekalian dan adakanlah pemujaan dengan persembahan bersama agar tujuanmu satu, dan sekata. Agar pikiranmu satu sehingga semua hidup bahagian bersama (Sadya,1990: 198-199).

Bontot (2011 : 106) memaparkan makna dari nilai-nilai saling asah, asih, asuh, sagilik-saguluk salunglung sabayantaka, briuk sapanggul, paras-paros sarpanaya, ngawe sukaning wong len adalah bersatu padu menyusun kekuatan untuk menghadapi ancaman, bahaya, masa-masa sulit, dengan memutuskan sesuatu melalui musyawarah mufakat, saling mengingatkan, saling menyayangi, dan saling membantu untuk mencapai tujuan bersama.

Kaitannya dengan etika atau susila bertujuan agar setiap tindakan harus dilaksanakan dengan kesadaran penuh sebagai persembahan kepada Tuhan. Bahkan dalam Yoga Sutra Patanjali diajarkan bahwa etika adalah dasar spiritual, merupakan aspek yang berpotensi untuk mendukung proses Upacara Nyambleh. Langkah eksplorasi yang penuh pegangan budaya, sangat mendasari menjadi sebuah latar penerangan untuk menerangi perjalanan lika-liku prosesi upacara. Upacara Nyambleh Juga terdapat aspek etika atau susila selalu dimaknai secara mendalam. Secara terpisah maupun langsung masyarakat sudah melakukan tapa didalam proses kegiatan ini sangat penting, unsur etika di dalam upacara Nyambleh adalah Warisan yang mengarah pada budaya yang sudah mengalami akulturasi yang sedemikian rupa, menjadi bentuk secara manifestasi tidak sama percis seperti semula. Namun secara implikasinya konsep-konsep yang terdapat didalamnya masih murni dan diterapkan dalam kelangsungan bermasyarakat. Dengan menyadari bahwa manusia diciptakan oleh Ida Sang Hyang Widhi Wasa untuk berbuat baik guna menemukan kebahagiaan dan kesejahteraan lahir dan bathin. Etika membina umat manusia untuk bisa menjadi anggota keluarga dan anggota masyarakat yang baik menjadi putra bangsa yang berkepribadian moral serta menuntun seseorang untuk memperkuat dirinya dengan sesama manusia (Mantra, 1992 dalam Suhardana, $2006: 20$ ).

Berdasarkan pemaparan diatas bahwa nilai pendidikan etika sangat jelas bahwa, bukan di dalam mempersiapkan sarana saja kita melalukan etika tetapi pada saat proses dan akhir upacra harus memiliki etika yang baik dan benar, dimanapun kita berada tetap melaksanakan pendidikan etika. Di dalam upacara nyambleh etika berbicara, 
bertingkahlaku sesama masyarakat ini biasa dilakukan guna nantinya mencapai suatu keharmonisan dalam pelaksanaan upacara nyambleh.

\subsubsection{Nilai Pendidikan Estetika}

Menurut Giri mengatakan bahwa: nilai pendidikan estetika yang terdapat dalam upacara Nyambleh terlihat pada prosesi pelaksanaan berlangsung, seperti ada kober yang berwarna-warni ibaratkan seperi pelangi, barong dan rangda sangat indah ini terdapat pada kuubnya barong, koob yang dimaksud adalah bagaimana antara badan dan kepala sangat cocok besar maupun kecilnya, kemudian ekornya barong yang dihiasi pernak-pernik seperti kaca, ada bunga kecil dan lain sebagainya, seni kekawin, seni karawitan atau gamelan, dan berbagai macam seni lainnya sehingga mengandung nilai estetis yang dapat menambah keindahan dalam pelaksanaan upacara Nyambleh. Seperti yang dikatakan oleh Yudabakti (2007:32) bahwa "agama adalah seni dan seni adalah agama. Seni dan agama identik. Ungkapan tersebut di atas pada kita khususnya masyarakat bahwa antara seni dan agama di Bali sangat berkaitan, Setiap penyelenggaraan prosesi upacara pasti ada kesenian dan setiap aktifitas pasti mengandung atau memuat ajaran agama, yang harus dipahami secara mendalam. Jadi seni adalah simbol kebenaran, kesucian, keindahan (estetika).

Berdasarkan dari pernyataan di atas, dapat dikaji bahwa nilai pendidikan estetika yang terdapat dalam upacara nyambleh adalah nilai estetika dalam arti spiritual yang mengandung aspek kesucian berdasarkan pikiran (manah) yang suci nirmala, keikhlasan (lascarya), kejujuran dan keindahan (satyam, sivam, sundaram). Di sampng itu nilai-nilai budaya dan ajaran agama Hindu untuk terus berupaya mengembangkan nilai seni yang dimiliki baik seni tari, seni suara maupun seni gamelan, secara tidak langsung nilai pendidikan estetika dalam upacara nymbleh dapat dirasakan oleh seluruh masyarakat pengempon maupun diluar pengempon pura, ini dapat kita lihat pada saat prosesi dimulai biasanya tamu mancan Negara atau lokal sering mengabadikan Fotofoto, dan tamu mancan Negara ini sangat senang, melihat estetika atau keindahan dalam prosesi upacara nyambleh.

\section{SIMPULAN \& SARAN \\ 4.1. Simpulan}

Nilai pendidikan yang terkandung dalam upacara Nyambleh di Pura Pererepan banjar denjalan Desa Batubulan, terdapat empat nilai 1. Nilai pendidikan tattwa yang dimaksud dalam upacara nyambleh adalah keyakinan masyarakat terhadap Ida Sang Hyang Widhi Wasa. 2. Nilai pendidikan religius ini terdapat pada masyarakat ngiring Petapaan atau Sesuunan sehabis itu masyarakat nunas pinget dan masyarakat tetap melaksanakan upacara nyambleh tersebut. 3. Nilai pendidikan etika yang terdapat pada upacara nyambleh adalah masyarakat melaksanakan ajaran tri kaya parisuda, bagaimana memiliki pikiran yang baik, perkataan yang baik, dan perbuatan yang baik dalam aktifitas masyarakat maupun dalam pelaksanaan upacara nyambleh, 4. Nilai estetis yang terdapat dalam upacara nyambleh padasaat prosesi berlangsung bagaimana umbulumbul yang berwarna warni, barong yang sangat indah disamping itu ada seni suara kidung maupun seni kerawitan maupun gambelan beleganjur. Nilai Pendidikan inilah yang terdapat dalam pelaksanaan upacara nyambleh.

\subsection{Saran}

Kepada pengempon pura perepan untuk tetap dapat menjaga kualitas upacara Nyambleh di samping itu upacara Nyambleh harus tetap di laksanakan. 
Kepada generasi muda dan tua khususnya pengempon Pura Perepan supaya tetap memiliki rasa religius atau kepercayaan dalam upacara Nyambleh yang sudah di yakinni dan tetap eksis.

Kepada para peneliti yang tertarik dengan masalah yang berkaitan dengan judul penelitian ini, agar mengadakan penelitian secara lebih mendalam sehingga hasilnya menjadi lebih sempurna.

\section{DAFTAR PUSTAKA}

Ngurah, I Gusti, dkk. 2005. Buku Pendidikan Agama Hindu Untuk Perguruan Tinggi. Surabaya: Paramita.

Suhardana, K.M. 2006. Menelusuri Kawasan Suci Berlandaskan Kitab Suci Weda. Denpasar : Empat Warna Komunikasi.

Suhardana Komang. 2010. Kerangka Dasar Agama Hindu Tattwa-Susila-Upacara. Agama. Surabaya: Paramita.

Sudharta,Tjok Rai dan I.B Oka Punia Atmaja.2001.Upadesa.Surabaya:Paramita.

Suryabrata, Sumadi. 2003. Metodologi Penelitian, Jakarta : PT. Rajagrafindo Persada.

Subagiasta, I Ketut. 2006. Teologi, Filsafat, Etika dan Ritual dalam Susastra Hindu. Surabaya: Paramita.

Saad, M. Soleh. 1990. "Chairil Anwar dan Telaah Kesusastraan (Sebuah Catatan Kecil

Dalam Lukman ali (ed) Tentang Kritik Sastra Sebuah Diksi”. Jakarta : Pusat Pembinaan dan Pengembangan Bahasa

Tim Penyusun. 2002. Kamus Besar Bahasa Indonesia. Jakarta : Bali Pustaka.

Wiana, I Ketut. 2007. Tri Hita Karana Menurut Konsep Hindu. Denpasar: Paramita Surabaya.

Wijayananda, Ida Pandita Mpu, 2004. Makna Filsafat Upakara dan Upacara. Surabaya: Paramita.

Yuda Bakti I Made Dan I Wayan Watra, 2007. Filsafat Seni Sakral Dalam Kebudayaan Bali Paramita Surabaya. 